\title{
The Ideal Confucian Mode for "Mother-in-law Being loving and Daughter-in-law Being Filial Pious" in Traditional China
}

\author{
Chen Shuhui ${ }^{1, a}$ \\ ${ }^{1}$ School of Tourism and Economic management,Chengdu University,Chengdu,Sichuan,China \\ a41674929@qq.com
}

\begin{abstract}
Key words: traditional China, mother-in-law being kind and daughter-in-law being filial pious, Confucian ethics, ideal mode
\end{abstract}

\begin{abstract}
The traditional Chinese family relations are governed by Confucian ethics that daughters must pay filial piety to the eldership. On the one hand, when a daughter got married, she became wife and must show respect to her parents-in-law, but on the other hand, "mother-in-law being loving" requires a mother-in-law to love her daughter-in-law. In this way, both a mother-in-law and a daughter-in-law will be happy. However, with the changes of traditional society, "mother-in-law being loving" wanes and "mother-in-law being powerful" waxes. "Daughter-in-law being filial pious" has been emphasized more and more by social rules, which made "mother-in-law being kind and daughter-in-law being filial pious" ideal.

In China the traditional orthodoxy that family and the state shares the same structure has brought countless ties between family structure and state order. Social stability and national prosperity can be achieved only when family harmony is ensured. Thus, the intellectuals try to build a perfect state for the relationship between mother-in-law and daughter-in-law. The traditional Chinese family relations are governed by Confucian ethics that daughters must pay filial piety to the eldership. On the one hand, when a daughter got married, she became wife and must show respect to her parents-in-law, but on the other hand, "mother-in-law being kind" requires a mother-in-law to love her daughter-in-law, as Guanzi says: "kindness is parents' lofty conduct," "filial piety is a daughter-in-law's lofty conduct," "a daughter-in-law will be filial pious if parents are loving without slackness," and "a daughter-in-law will be given good reputation if she is filial pious without slackness. " [1]In one word, a mother-in-law should be kind, and a daughter-in-law should obey the rule of filial piety, but factually mother-in-law and daughter-in-law are not as equal as the Confucian mode requires though.
\end{abstract}

\section{A Mother-in-law Being Powerful and Loving}

In traditional Chinese patriarch clan system, the priority of men and elders made women subordinate to men and their family, but after Confucius (B.C. 551 - B.C. 479) gave a high position to filial piety, the women having offspring enjoy the higher place and stronger power than their sons and daughters. In a family does not have male elders, a mother will have a high position and even become the head of a family. [2]

The power of mother-in-law in patriarch clan system has been ensured from three aspects. First, a daughter-in-law does not have economic rights. The ancient ritual and law require that the children whose parents or grandparents are alive cannot own private property to prevent the dispersion of family possessions. Being the outsider tied to her husband's family by marriage, a daughter-in-law almost does not have any rights of property, as the saying goes: "a son's wife does not have private possessions, does not have private livestock, does not have private tools, dares not borrow things, dares not give things.".[3] A daughter-in-law is not allowed to have private property. Even if the gift is granted by others, a daughter-in-law must "accept and present it to parents-in-law." When parents-in-law accept it, a daughter-in-law should feel happy, but when parents-in-law object the gift, she must decline it. If a daughter-in-law cannot decline it, she can accept it but cannot use it. The gift should be kept well in case one day parents-in-law need it. If a daughter-in-law wants to present it to others, she must ask for permission from parents-in-law first. 
[4] From Tang (618-907) to Qing (1636-1912), to protect the elder members' property rights, every dynasty legitimated that younger generations cannot appropriate elders' property or store up property outside family.

Second, a mother-in-law owns certain power in deciding her daughter-in-law's marriage. In the ancient Chinese marriage system, young men and women, required by rituals and laws, must obey parents' order. A mother has certain power to choose her daughter-in-law. Even the relation between wife and husband could be influenced by parents-in-law. One of the seven types of grounds for a husband to cast off his wife and send her back to her parents is poor service to parents-in-law. The often recounted marriage stories such as Jiao Zhongqing and Liu Lanzhi, and Lu You (1125-1210) and Tang Wan, all end with divorce caused by mothers-in-law. Therefore, the first task for a new daughter-in-law is to please parents-in-law even if she is dissatisfied.

Third, a mother-in-law has rights to punish her daughter-in-law. For example, parents-in-law are empowered to administer corporal punishment to their daughter-in-law, and draw the support from government to punish the unfaithful daughter-in-law.

A mother-in-law can enjoy the absolute power, but meanwhile she is required to fulfil her obligation. If a mother-in-law hopes to have a filial pious daughter-in-law, she must be loving first. Confucius's student Zixia (B.C. 507-?) sighed when he heard that Wenbo's mother talked about the teaching of her mother-in-law, "In past, for the married women who are too late to serve parents-in-law, it is called misfortune. A married woman, learns things from parents-in-law." [5] Both husband and wife must learn protocols and experience of housekeeping from the husband's parents who are responsible for teaching them. In Xinshu Jia Yi (B.C. 200- B.C. 168) says: "If a husband is kind, it is good; if a wife is soft, it is right; if a mother-in-law is loving, it is smooth; if a daughter-in-law is obedient, it is docile. This is the essence of ritual.".[6] It is thus evident that whether a mother-in-law is loving has direct impact on whether she deserves her daughter-in-law's service. Moreover, Liji tells us that a mother-in-law should let her daughter-in-law rest while laboring. Even if a daughter-in-law is not filial pious, her mother-in-law should teach her with patience instead of anger. If a daughter-in-law does not take her mother-in-law's advice, she may be blamed and even get a divorce ordered by her mother-in-law. Nevertheless, a mother-in-law would better not publicize that her daughter-in-law disobeyed rituals.[7] When a male family leader died and his son succeeds him, the wife of the son should take care of household duties. At the same time, the mother-in-law ought to hand over her job to the successor for her limited energy.

\section{Female Virtues and A Daughter-in-law's Filial Piety}

The piety of a daughter-in-law to parents-in-law is merely virtue or duty having nothing to do with kinship. A daughter-in-law needs to be educated and warned constantly to be aware of her duty first, and then she is able to fulfil her duty well. As we could expect, many books aiming to instruct women how to conduct themselves and manage household came into being. These books mainly focus on four facets. First, filial piety is stressed so much that whether a daughter can be filial pious to her parents and parents-in-law is the essential standard for a qualified daughter. Second, a wife's duty is to assist her husband in serving parents-in-law, take care of and respect her husband. Third, a mother should be highbrow and able to teach children to obey rituals and social rules. Fourth, a wife should fulfil her family duty such as managing household well, dealing with interpersonal relations, and improving family atmosphere. The above four facets are mainly associated with married women. Put simply, a daughter-in-law must be filial pious, a wife must assist her husband in paying filial piety, a mother must teach her children to be filial pious, and a female housekeeper must respect her parents-in-law.

The essence of female virtues is to pay piety to parents and parents-in-law. Nüxue says: "Women must take virtue as the principle thing... The first thing is to serve husband and parents-in-law, the second thing is to establish harmony among brothers-in-law and sisters-in-law, and to get on well with wives of brothers and concubines of their own husbands."[8] Jiaonü yigui says: "When a daughter is in the hall, she must respect her parents. ".[9] It means that a daughter must serve her parents reverently before marriage. For example, a daughter should inquire after parents' well-being 
every day, accept parents' teaching humbly, show solicitude towards parents' life, take care of the sick parents, and arrange funeral ceremony and sacrifice for the dead parents. After a daughter marries her husband, her parents-in-law became the recipient of her piety as the saying goes. What does "obedient" mean? A daughter-in-law cannot be disobedient or slack to the order of her parents or parents-in-law. If a daughter-in-law does not like the food, she must taste it for her parents and parents-in-law; if she does not like the clothing, she must wear it for her parents and parents-in-law; if she does not like to be replaced in doing something, she can do it again in person only after her mother-in-law gives it to her and lets her do it. Literally, Zheng xuan's commentary requires a daughter-in-law to deal with all things perfectly in family.

Apart from practicing filial piety, a wife ought to persuade and assist her husband to practice piety. The chapter "Persuade a husband to be filial pious" in Xinfu pu holds that a daughter-in-law's piety to parents-in-law is just the primary requirement. For a wife, reminding her husband of his duty of a son, urging him to practice piety, and reforming the unfilial husband with her filial behaviors are essential. Zeng Yinhong is a dutiful son and his wife, Wang, is well-known for her filial conduct. When they suffered from floods, Wang did not eat food in the daytime and supported her mother-in-law from weaving. When Wang's mother-in-law had eye disease, Wang licked her mother-in-law's eyes with tongue to help her mother-in-law regain the sight. When Wang's mother-in-law lost all the teeth, Wang breast-fed her for three years. Wang's filial conduct impressed the world.[10] Another woman surnamed Han was named for her service to her sick mother-in-law without rest.[11] Usually, a filial son has few time and energy to serve parents at home because of the labor division of male and female. Thus a wife must shoulder the responsibility of her husband to serve parents and raise children. Otherwise, it is difficult for a son to take care of his family members.

Due to the combination of Confucian filial tradition and the view that male differs from female, Confucian ethics try to build an ideal mode for mother-in-law and daughter-in-law that a mother-in-law is loving and a daughter-in-law is filial pious. Although a mother-in-law has higher family status than her daughter-in-law, she should give care and love to her daughter-in-law. Simultaneously, a daughter-in-law should serve her mother-in-law with respect, assist her husband in practicing filial piety, teach children to be filial pious, manage household well, and get on well with all the relatives. In this way, family harmony can be reached, and furthermore, social stability and national prosperity will be ensured.

\section{The Filial Piety of A Daughter-in-law Weighing more than the Love from a Mother-in-law}

In the traditional Chinese society dominated by the small-scale peasant economy, the basic units of a country are the local family clans in which the most important relationships are parent-children and husband-wife, the former regularized by Confucian filial piety overriding the latter regularized by the distinction between male and female.

According to the traditional gender hierarchy and the rule of filial piety, a son must pay piety to parents, a wife must obey her husband, and a wife must pay piety to parents-in-law. That is to say, a wife should respect her husband's family rather than her own family. A mother-in-law has certain rights of control over a daughter-in-law who has the duty to serve her mother-in-law. Despite that filial piety does not emphasize the gender difference and many commentaries make no exception between male and female, there is distinction of rank for husband and wife and therefore the rule of filial piety for a daughter-in-law is harsher than that for a son.

Confucius has set the duty for a loving mother-in-law, but it is mainly reflected in some female learning books in which the content about mother-in-law's duty seems much less than that about mother-in-law's rights. Furthermore, the national laws and family rules did not expressly require a mother-in-law to be loving, let alone punish an unqualified mother-in-law. The bi-directional equal requirements for mother-in-law and daughter-in-law get unfair anymore with the augment of parents' power. The rights of a mother-in-law have been valued more and more, while the requirements for a loving mother-in-law became invisible or they are touched upon to persuade a 
daughter-in-law to do self-surrender before a mother-in-law. A poem titled "Serving parents-in-law" by Li Yuqing in Qing reads: "(A mother-in-law) loves her daughter-in-law more often than her son. In most cases, a mother-in-law is loving. Usually she is loving. Occasionally she is not loving." This poem raises a mother-in-law's attitude she should have to a daughter-in-law. In reality there are many mean mothers-in-law whose daughters-in-law cannot blame mothers-in-law for harshness but examine their own filial behaviors. Filial piety is considered as a daughter-in-law's duty, but a mother-in-law has not been required to be loving any more. A mother-in-law's family status became so high that a daughter-in-law will be punished by rituals and laws if she disobeys her mother-in-law. Behind the ideal mode that a mother-in-law should be loving and a daughter-in-law should be filial pious is the fact that a mother-in-law is honored but a daughter-in-law is humble. The real relationship between a mother-in-law and a daughter-in-law gradually became prevailing, and has been legalized and systemized by Confucianism, family rules and national laws. Females also were educated to accept the mainstream values to be good at self-discipline without any urging, which shaped the real relationship between a mother-in-law and a daughter-in-law.

\section{References}

[1] Liu Ji, Guanzi buzhu ,Wenyuange Sikuquanshu ben, vol. 20, pp.209.

[2] Gao Shiyu, Tangdai funü ,Xian: Sanqin press,p.226-227,2011.

[3] Lü Youren, Lü Yongmei, Liji quanyi, Guiyang:Guizhou renmin press, p.405,2008.

[4] Zheng Xuan (127-200), Liji,Sibu congkan Jingsongben ,vol.8, p.163-164.

[5] Dong Zengling, Guoyu Zhengyi,Qing Guangxu Zhangshi xuntang keben, vol.5, p.190.

[6] Wang Zhouming, Xu Chao, Jia Yi ji jiaozhu.Beijing: Renmin press, p.215,1996.

[7] See Lü Youren, Lü Yongmei, Liji quanyi,Guiyang: Guizhou renmin press, p.402,2008.

[8] Lan Dingyuan (1680-1733), Luzhou quanji,Xiamen: Xiamen daxue press,p.605,1995.

[9] Chen Hongmou(1696-1771), Wuzhong yigui, Qing Qianlong Peiyuantang kehui yinben, p.70.

[10] Li Mingwan, Feng Guifen, Tongzhi Suzhou fuzhi, vol. 128, in Zhongguo difangzhi jicheng, Nanjing: Jiangsu guji press,vol.10,1990.

[11] Jin Wulan, Li Fuyi, Guangxu Xin Kun liangxian xuxiu hezhi, vol. 36, in Zhongguo difangzhi jicheng, Nanjing: Jiangsu guji press, vol.16,1990. 